\title{
Socio-Economic Impact of Informal Financial Sector and Inclusive Growth: Empirical Evidence from North Central-Nigeria
}

\author{
Yelwa Mohammed $^{1}$, Hussainatu Abdullahi ${ }^{2}$, Yahya Zakari Abdullahi ${ }^{2}$ \& Awe Emmauel Omonoyi ${ }^{3}$ \\ ${ }^{1}$ Department of Economics, University of Abuja-Abuja, Nigeria. \\ ${ }^{2}$ Department of Economics Usman Danfodiyo University, Sokoto, Nigeria. \\ ${ }^{3}$ Department of Economics University Of Abuja- Abuja. \\ Correspondence: Yelwa Mohammed, Department of Economics, University of Abuja-Abuja.
}

Received: September 2, 2015

Accepted: September 16, 2015

Available online: October 14, 2015

doi:10.11114/aef.v2i4.1142

URL: http://dx.doi.org/10.11114/aef.v2i4.1142

\begin{abstract}
The paper examines the socio-economic impact of informal financial sector and inclusive growth in north central Nigeria. The notion behind inclusive growth entails analysis how employment opportunities arise and change with growth process with time. Economic growth can be accompanied by an increase in informal sector employment. Informal financial sector may support growth by reducing cost of borrowing, collateral, bureaucratic process and improving competitiveness. However, a well-functioning and regulated informal financial economy will be a critical prerequisite to achieve sustainable growth in north central-Nigeria. And also, a widespread informal financial sector with regard to employment, enterprise, and productive activities is frequently perceived as a barrier to full participation in the economy and as a hindrance to long-run economic development and poverty alleviation in this region. This is because the link between, informal financial sector, growth and inclusiveness is not fully understood. Inclusive growth has been defined as growth that takes place in a context in which economic opportunities-including employment opportunities expand, the poor's access to these opportunities improves, and inequalities are reduced. This paper seeks to investigate the socio-economic impact of informal financial sector activities, inclusiveness' and economic growth in north central - Nigeria. A systematic random sampling method was used to collect data from 500 informal financial sector operators in Abuja, kogi and Niger states. A multivariate panel logit model statistic was used to analyze the data in order to identify the perception of socio-economic impact of Informal financial sectors on economic growth in north central- Nigeria. The findings revealed that informal sector operators has a positive and significant impact on growth in the region; while poverty-mentality, illiteracy, high inflation, low infrastructure, access to credit, social safety nets and information dissemination are the major problems encountered by these institutions. The paper recommends among other things the education of the rural poor to embark on viable projects, infrastructural development and favorable government policies so as to regulate the sector becomes relevant.
\end{abstract}

Keywords: Economic growth, Economic development, poverty, inclusive growth, informality.

\section{Introduction}

Nigeria economy has been characterized with the Small and Medium scale Enterprises (SMEs) and its development will enhance the country's sustainable growth and development. The inability of the formal financial institutions to provide financial services to the urban and rural SMEs, coupled with the non-sustainability of government to finance development projects contributed to the slow growth of private sector-led in Nigeria. Before the emergence of formal financial institutions, an informal financial activity has been flourished and contributed tremendously in area of job creation and poverty alleviation all over the country.(yelwa,2011).

Informal finance is provided by traditional groups that work together for the mutual benefits of their members. These groups provide savings and credit services to their members. The informal finance arrangements operate under different names: 'esusu or ajo' among the Yorubas of Western Nigeria, 'etoto' for the Igbos in the East and 'adashi' in the North for the Hausas (CBN, 2000). The key features of these informal schemes are savings and credit components, informality of operations and lower interest rates in relation to the formal banking sector. The informal associations that operate traditional microfinance in various forms are found in all the rural communities in Nigeria (Otu, et al, 2003). 
The Central Bank of Nigeria survey (2001) indicated that the operations of formal microfinance institutions in Nigeria are relatively new, as most of them were registered after 1981. Most of the MFI were also registered from 1982 as non-governmental organizations (NGOs). They operate in both urban and rural areas.

The bulk of credit beneficiaries were women, as most of the MFIs began as NGOs that had the promotion of female welfare as the basis for their establishment. Apart from the general belief that women are marginalized in terms of economic opportunities and should therefore have separate promotional agenda, the MFIs are of the view that women perform better than men in managing meager resources and promoting micro enterprises. Other reasons were that the ego problem of men makes it difficult for them to solicit for small sums of money; and that cultural practices prevent men from engaging in certain businesses, such as petty-trading, hair-dressing, etc.

Unlike in the money deposit banks, asset based collateral is de-emphasized by the informal financial sector (IFS). Lending is done on group basis and a group is made up of between 5 and 10 clients. The collateral is the collective pledge of the group to repay, based on community recognition. In addition, the IFS concentrate on short term financing, owing to the large demand for loans and their limited assets. High percent of their financing was for trading activities. Credit to the service sector was very minimal and the IFS gave no loans for consumption. All the clients were low-income individuals, operating micro enterprises. The disproportionate coverage of commerce in the loan portfolios of IFS is attributed to the quick and high returns that come from investments in the sector, compared with the long gestation periods and lower returns that are associated with businesses in agriculture and manufacturing.

However, this paper therefore will establish the need to empower the poor, which has been estimated to be on the increase through the operation of informal financial institutions as a strategy for poverty reduction. Presently, it has become very difficult if not impossible for many Nigerians to live above the poverty line. Accessibility to credit facilities is also very difficult for women and men, farmers and people who are poor. Yelwa,(2011). The inability of the formal financial institutions (FFI) to make funds available to reach the poor segment of the population, due to the stringent conditions attached to loan has increased the relevance of the Informal Financial Institutions (IFIs) such as money lenders, pawnbrokers, Rotating Saving and Credit Associations (ROSCA) and so on, that provide credit service for the needy in short notice with little or no restriction. Adeyemi, (2008).

In relation to the above, the failure of most programmes by successive governments in Nigeria to tackle the menace of poverty among the general population due to political instability, corruption, bureaucratic bottleneck, lack of sincerity of purpose, elitist orientation of the programmes and the unwillingness of the formal financial institutions to grant loans/credit facilities to the poor resulting from non-provision of collateral security have been held responsible for this situation. The concerns generated by the prevalent situation have brought the need to focus attention on the operations of Informal Financial Institutions. Yelwa,(2011)

However, it is on this basis that the research questions were formulated:

i. Is there any significant relationship between Informal Financial Sector and Small and Medium scale Enterprises in North central Nigeria?

ii. Is there any significant relationship between Informal Financial Sector and Income generation in north central Nigeria?

iii. Is there any significant contributions of the Informal Financial Sector to employment generation in north central Nigeria?

The main objective of this study is the socio-economic impact of informal financial sector and inclusive growth in North Central Nigeria. This study will be of paramount importance to economic decision-makers, as it will equip them with the knowledge and skills needed to tackle the pressing issue of capital unavailability for the SMEs in Nigeria. Also, to those who would like to carry out further research on this topic, it would be of valuable help in the course of their research.

\section{Literature Review}

Informal finance programme has been viewed as a unique programme for the reduction of vulnerability, and hence the achievement of the Millennium Developmental Goals (Adamu, 2007).

Berko (2001) investigated that the primitive means of informal financing institutions were the slavery, forced human labour, child Marriage and the practice of "Iwaga" in Yoruba area in which a borrower uses his own wife or daughter as collateral for the loan. According to him, these dehumanizing of human race practices had been phased out in Nigeria because of religion and civilization.

Umebali (2002) sees informal credit institutions to include all classes of credit, savings associations and markets operating outside the formal financial system guidelines. They gained their popularity as a result of non cooperative attitudes of some conventional banks and other non-banking financial institutions in giving loans to the less privileged 
or poor. These institutions are often made up of heterogeneous savers and lenders which include but are not limited to: Local Savings Scheme This is equally called daily savings or daily contributions scheme. It is a modern approach to local lenders and borrowers in which they play their local intermediation role of transferring funds from surplus side to deficit unit, (Berko, 1995).

Chukwu (1990) described this type of finance as a kind of insurance coverage for the members of the family both extended and immediate. In such case, common purse exists into which every well-to-do family members is expected to contribute his or her own quota and the funds so contributed can be used to give financial support to any members of the family that is not well-to-do.

Cooperatives association these are voluntary association or group of people coming from the same socio-economic background who pull their resources together for the purposes of solving their common problems through self-help and mutual trust. Cooperative has been the indigenous mechanism and technique employed by the people to identify their felt needs, choose what they want and take cooperative action to satisfy their needs, (Okonkwo, 2012). In Nigeria, cooperative societies are classified into producers, consumers and financing cooperatives. It is traditionally required that members of any of these informal financial forums should have common economic or social goals which they purse for the betterment and improvement of their standard of living.

In the view of Osuntogun \& Adeyemo (1981), the informal financial market is an indigenous system of saving in varying forms which can be broadly summarized as a situation in which a group of people come together, contribute fixed amount at fixed intervals and assign the total amount contributed to an individual member on rotational basis or offer credit to members and share their accumulated savings at certain time in the year rather than on rotation.

Micro-finance is a term used to refer to different methods for giving poor people access to financial services. Irobi (2008) defined microfinance as the provision of financial services such as credits (loans), savings, micro-leasing, micro-insurance and payment transfers to economically active poor and low income household to enable them engage in income generating activities or expand/grow the small businesses. Microfinance is sectional defined as a financial intervention that focuses on the low-income group of a given society. The intervention primarily involves credit services and may also include savings, insurance on credits and savings. Irobi (2008).

\subsection{Empirical Review}

Earlier studies about informal financing have evaluated whether micro-credit programs in Nigeria reach the relatively poor and vulnerable in their operations. Recent studies have shown evidence of positive impact as it relates to first six out of seven Millennium Goals (Adamu, 2007; Irobi, 2008; Wrigth, 2000; Zaman, 2000; McCulloch and Baulch, 2000), all subscribed to the believe that informal finance is an effective and powerful tool for poverty reduction.

According to Khandker (1998), in his studies using statistical method on assessment of impact of Informal finance among three Bangladesi programs found that every additional takas lent to a woman add additional of 0.18 taka to annual household expenditure. Similarly, in an updated study using panel data in Bangladesh, Khandker (2005), found out that each additional 100 taka of credit to women increase total annual household expenditures by more than 20 taka. These studies showed overwhelming benefit of increase in income and reduction of vulnerability.

On the other hand, some authors have challenged the positive effects of Informal Financial Sector on poverty alleviation. For instance, Hulme and Mosley, (1996) while acknowledging the role of microfinance can have in helping to reduce poverty, concluded from their research on microfinance that "most contemporary schemes are less effective than they might be". They stated that microfinance is not a panacea for poverty - alleviation and that in some cases the poorest people have been made worse-off by microfinance.

Dunn and Arhucle (2001), used an analysis of covariance to examine loans to micro entrepreneurs for 305 households in Peru. The study uses data at two points in time and looked at changes in borrowers relative to control group who have not received micro-credit. 'The study suggests that there are significant differences between the borrowers and the control of group in terms of enterprise revenue, productivity, fixed assets and employment creation for other people.

Toh and Urata (1994), examined how Japan's public and private sectors support small and medium-size enterprises (SME's). Their findings based on a survey of 107 firms revealed that it accounted for about 35-60 percent growths in the productivity of the (SME's). Similarly, Kim and Nuggent (1994), evaluated the effectiveness of private and collective technical, marketing and financial support systems for the Republic of Korea's small and medium-sized enterprises and entrepreneurs. They observed that financial assistance was the most critical form of support for Korean's SME's and that government intervention in finance was very pervasive. The Korean government had made extensive use of parastatal finance institutions, targeted credit (micro-credits), and credit guaranteed schemes.

\subsubsection{The relationship between Formal and Informal Financial Institutions}

Generally most intellectual debate on informal finances has been viewed from two perspectives namely 'the residual' 
and 'the dualism' paradigm. The residual paradigm believed that the inefficiencies generated within the formal financial system and the improper way of adaptation of world's formal financial condition led to the existences of informal finance. This paradigm originated from the works of MCKinnon (1973) and Shaw (1973). They argue that informal finance stems from the excessive regulation of the Formal Financial Institution through the use of direct credit policies, interest rate ceilings and preferential allocation of credit which created distortion in the economy. The distortion led to high cost of fund to the poor, rural dwellers, small scale entrepreneurs and other disadvantaged groups thereby accentuating the development of the Informal Financial Institutions.

Furthermore, Bouman and Houtman as cited in Fischer (1994) argue that the rural economies of many Asian and African countries require the financial system to generate turnover of small loans with low risk and low transaction cost, but the banks of formal institutions do not have the managerial capacity to small loans since the local lenders (informal institutions) are already involved in providing such services. In line with this position, Ardener and Fitchette (1992) believed that informal institutions are better than the formal institutions in supplying short term credit/loans to the poor, more closer to their client and are thus in a better position to give recipe to changing financial needs than the formal.

The second perspective which relates to the dualism paradigm believes that IFI exist as a result of other motives beyond the purely economic. According to this school of thought, IFI exist due to subordinate role it plays to the FFI thus creating market segmentation. In their view the occurrence of market segmentation is not due to regulation but because of the fact that the IFI serve in redistributing income among community members and provide a form of social security by meeting their fluctuating liquidity needs (Hugon, 1990 as cited in Soyibo, 1996). While it is costly in formal institution to acquire information about clients, informal utilizes local personal information resulting into a weak legal system which inhibits contract enforcement thereby results in credit rationing of potentials borrower without collateral. The market segmentation can be filled by informal agent as the collateral is replace by reputation, group responsibility and interlinked transaction.

Ardener and Burman (1995) argued further that informal finance is efficient in responding to the socio economic conditions of the poor as a result of the availability of resources without depending on market segmentation. Hill as cited by Ardener and Burman (1995) pointed out that rural poor need not to be learned on the saving habit since they have already engaged in the activities among themselves and need not to resemble any formal institution using the West African economies experience. He continued his argument in 1970s and 1980s with the Indian case study and later concluded that informal credit market evolved faster in rural areas especially where agriculture predominate and there is concentration of formal finance. In such situation, informal institutions compete with formal institution and still survive the competitiveness, financial viability and low cost of operation (Bouman, 1995).

Informality exist due to inefficiencies caused by market segmentation which prevents the formal institution to enter into the market since the informal cannot help but be replaced by formal one which is tends to eliminate the segmentation as the informal financial system develops and are less efficient in conducting financial transaction. An increasing body of analytical work has attempted to give an explanation to the functioning of credit markets using the new theoretical developments. Challenging paradigms of competitive equilibrium have tried to explore the implication of incomplete market on market segmentation and imperfect information for the operation of credit market in developing countries thus providing a theoretical foundation for policy intervention.

\subsection{Theoretical Framework}

The theoretical framework for this study is rooted to the neoclassical theory of Financial Constraint and Model Generation. This study applies the neoclassical theory of financing constraints to investigate whether informal financial institutions improved access to credit for microenterprises in Nigeria. The financing constraints approach, pioneered by Petersen, Fazzari and Hubbard, (1988) simply tests for differences in sensitivity of investment to internal funds in enterprises with different levels of informational capacity by splitting a sample of enterprises into subsamples. For each sub-sample, a reduced- form investment equation is estimated, where investment is modeled as a function of the enterprise's internal funds, usually defined as revenues minus expenses and taxes and used as a proxy for changes in net worth, as well as controls for enterprise-specific characteristics and investment opportunities determined from a variety of theoretical perspectives (Hubbard, 1998). Though the financing constraint is an empirical approach, its theoretical underpinnings come from recent developments in the literature on investment. Cleary, Povel, and Raith (2007) show that for positive or slightly negative levels of enterprise wealth, investment is positively related to internal finance.

\section{Methodology}

\subsection{Nature and sources of Data}

This study relied on both primary and secondary data. The primary data was obtained using questionnaire. A total of 500 questionnaires were distributed across theses states to registered IFI operators and SMEs by using systematic random sampling procedure; this is to reduce the chances of error which a small population size will cause. Apart from 
the use of questionnaire, personal interview was conducted to enable the researcher obtain more information from those who were not able to express themselves clearly in writing.

However, the secondary data was obtained from the Central bank of Nigeria (CBN), National Bureau of Statistics (NBS) and World Bank data. The study was conducted in the North Central, Nigeria

\subsection{Model specification}

The model by Cleary, Povel, and Raith (2007) assumes that the cost of debt financing is endogenously determined and investments are scalable, meaning that change in the marginal cost of debt finance affects both the decision to invest and the choice of investment. This assumption permits the use of a logit model similar to the one used by Johnson, McMillan, and Woodruff (2002) to study investment decisions by small firms in transition economies.

The logit model assumes logistic distribution of the probability of an event; it tests for the presence or absence of a thing or an event.

However, to assess the role of informal financial institutions as inclusive growth in Nigeria with some selected states in North central as a case study, the study employed the Logit Probability Model given as follows:

$$
\begin{aligned}
L=\frac{\operatorname{In}(P)}{\operatorname{In}(1-P)} & \\
& =\beta_{0}+\beta_{1} E D U+\beta_{2} L N R+\beta_{3} R E P L+\beta_{4} G U A R+\beta_{5} Y A L+\beta_{6} S M E D E V \\
& +\beta_{7} E M P G E N+\mu
\end{aligned}
$$

Where:

$\mathrm{L}=\mathrm{P}=1$, If Informal Financial Sector promotes growth in some selected states in North central; (1-P), if otherwise.

$\mathrm{EDU}=$ Entrepreneur level of education (This is measured by the total number of years the entrepreneur spent in educational attainment)

LNR= Lending Rate (This is the cost of capital borrowed)

REPL $=$ Repayment plan (Binary: $I$ if repayment plan is convenience, 0 if otherwise)

GUAR= Guarantor. This describes the individual who pledges that a debt will be paid (Binary: 1 if guarantor was available, 0 if otherwise)

YAL $=$ Earnings after loan

SMEDEV= SMEs Development (Binary: 1 if IFS have impact on SMEDEV, 0 if otherwise)

EMPGEN= Employment generation (Binary: 1 if IFS have impact on EMPGEN, 0 if otherwise)

Here, $\mathrm{P}=1$, if Informal financial Sector promotes growth in North central; (1-P), if otherwise.

The dependent variable is a dichotomous variable. The independent variables in the model are admixture of quantitative and qualitative variables, while $\beta_{0}, \beta_{1}, \beta_{2}, \beta_{3}, \beta_{4}, \beta_{5}, \beta_{6}$ and $\beta_{7}$ are the parameters of the model to be estimated. The error term, $\mu$ which represents unobserved values, is assumed to be normally distributed, with zero mean and constant variance.

\subsection{Methods of Data Analysis}

The Maximum Likelihood (ML) method is used to obtain estimates for the specified Logit probability model. The justification for using ML method is due to the fact that neither the ordinary least squares (OLS) nor the weighted least square (WLS) is helpful or adequate for estimating the Logit model. Moreover, that the Logit model is a nonlinear model. The parameter estimates of the specified Logit model are not directly interpretable with respect to magnitudes of effect but only interpretable with respect to the direction of effect on probability (Patrick et al., 1996).

However, the data gathered were grouped and arranged in tabular form and then analyzed. A descriptive method of data analyses is used in this research. The descriptive statistic relied on frequencies obtained using Logit model. The model is used to regress the probability of whether informal financial institutions are able to enhanced growth in North centralNigeria on a set of both economic and non-economic factors.

The Logit model is known to produce statistically sound result. The model is known to produce results that can be easily interpreted and the method is simple to analyze in economics applications. Furthermore, Logit model is one of the most popular binary response model used in empirical analysis. 


\section{Analysis of Results from Descriptive statistics}

\subsection{Characteristics of Respondents}

Table 4.1 Educational Qualifications of the respondents.

\begin{tabular}{lll}
\hline $\begin{array}{l}\text { EDUCATIONAL } \\
\text { QUALIFICATION }\end{array}$ & NO. OF RESPONDENTS & PERCENTAGE \\
\hline None & 5 & $3.3 \%$ \\
Non - formal & 8 & $5.33 \%$ \\
School certificate & 25 & $16.7 \%$ \\
OND & 30 & $20 \%$ \\
HND & 21 & $14 \%$ \\
Degree & 48 & $32 \%$ \\
Master degree \& above & 13 & $8.7 \%$ \\
Total & $\mathbf{1 5 0}$ & $\mathbf{1 0 0 \%}$ \\
\hline
\end{tabular}

Source: yelwa,eta,al. 2015.

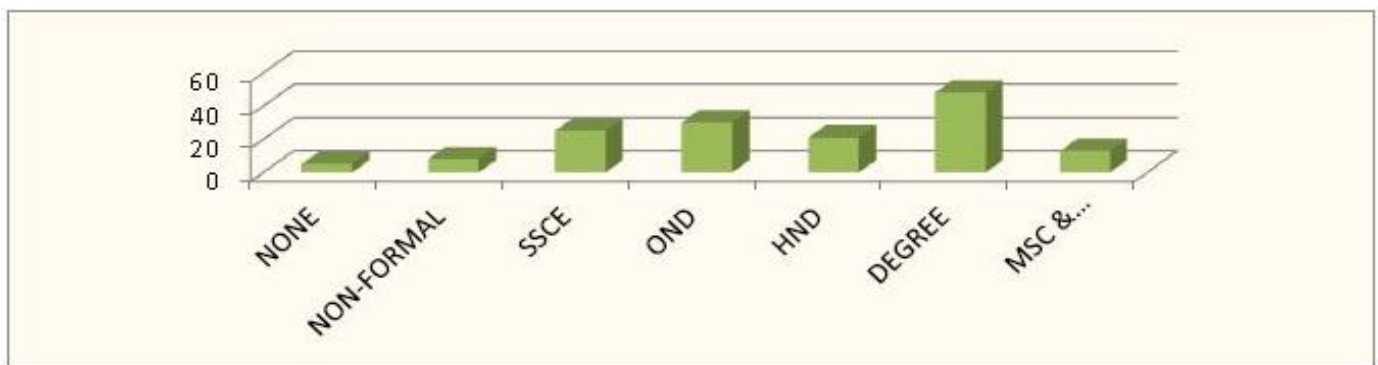

Source: yelwa, eta,al. 2015.

Figure: 4.1 pictorial Analysis of Educational attainments of Respondents

Table:4.1: shows that 5 respondents representing (3.3\%) have no educational qualification, 8 representing (5.33\%) are educated non formally, 25 respondents $(16.7 \%)$ have obtained school certificate, 30 respondents $(20 \%)$ have obtained OND, 21 respondents (14\%) have obtained HND. 48 respondents (32\%) are first degree holders while 13 other respondents representing $(8.7 \%)$ have masters degree and above.

Table 4.2 Lending Rate of Respondents

\begin{tabular}{lll}
\hline LENDING RATE $(\%)$ & NO. OF RESPONDENTS & PERCENTAGE $(\%)$ \\
\hline $2.00-2.99$ & 35 & $23.3 \%$ \\
$3.00-3.99$ & 70 & $46.7 \%$ \\
$4.00-4.99$ & 20 & $13.3 \%$ \\
$5.00-$ above & 25 & $16.7 \%$ \\
Total & 150 & $100 \%$ \\
\hline
\end{tabular}

Source: yelwa, eta,al. 2015.

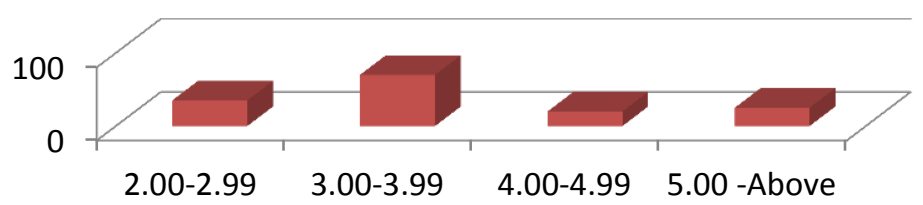

Figure. 4.2 Pictorial Analysis of Lending Rate of Respondents

Source: yelwa, eta,tal. 2015

Table 4.2: shows the distribution of lending rate of the respondents. 35 respondents representing (23.3\%) got the loan at the rate $2.00-2.99 \% .70$ respondents representing $(46.7 \%)$ had the loan at 3.00-3.99\%. 20 respondents representing (13.3\%) had it at $4.00-4.99 \%$ while 25 respondents representing (16.7\%) had it at 5.00- above. This shows that the majority of the respondents got the soft loan between 3.00-3.99. 
Table. 4.3 Repayment plans of respondents

\begin{tabular}{lll}
\hline REPAYMENT PLAN & NO. OF RESPONDENTS & PERCENTAGE \\
\hline YES & 125 & $83.3 \%$ \\
NO & 25 & $16.67 \%$ \\
Total & 150 & $100 \%$ \\
\hline
\end{tabular}

Source: yelwa, etal,al.2015

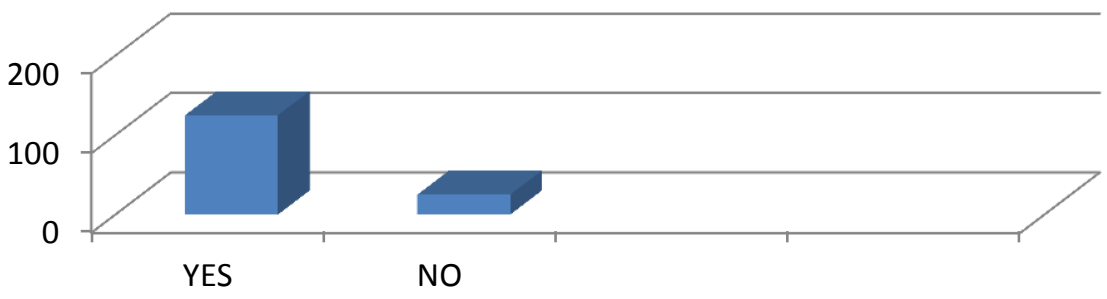

Figure. 4.3 pictorial analysis of respondent's repayment plans

Source: yelwa, eta, al.2015.

Table: 4.3: shows the conveniences of payment by the respondents. 125 respondents representing (83.3\%) agreed to convenience repayment while 25 respondents representing (16.67\%) disagreed. This show that majority of the respondents agreed that IFS loan repayment is convenience.

Table 4.4 Respondent's guarantors

\begin{tabular}{lll}
\hline RESPONSE & NO. OF RESPONDENTS & PERCENTAGE \\
\hline Yes & 135 & 90 \\
No & 15 & 10 \\
Total & 150 & 100 \\
\hline
\end{tabular}

Source: yelwa,eta,al. 2015.

Figure 4.4 Depicts pictures of respondent's guarantors

Source: yelwa, eta,al. 2015.

Table: 4.4: shows that 135 respondents representing $90 \%$ have guarantors as demanded by the IFI while 15 respondents representing $10 \%$ did not. This shows that the demand or procedures in accessing IFI loan is highly relaxed compared to the formal financial institutions

Table. 4.5 Respondent's earnings from business

\begin{tabular}{lll}
\hline RESPONSE & NO. OF RESPONDENTS & PERCENTAGE \\
\hline Yes & 135 & 90 \\
No & 15 & 10 \\
Total & 150 & 100 \\
\hline
\end{tabular}

Source: yelwa, eta,al. 2015.

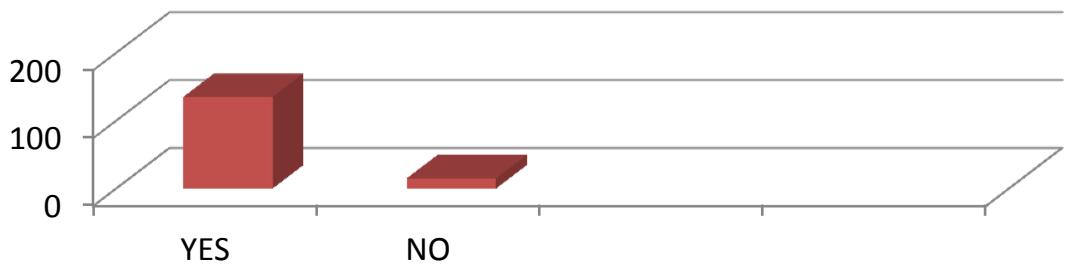

Figure 4.5: Respondents earnings from business 
Source: yelwa, eta,al. 2015.

Table $\mathrm{F}$ above shows that 135 of the respondents representing $90 \%$ experienced improvement in earnings while 15 respondents representing $10 \%$ did not.

Table 4.6 contribution of IFS to SMEs

\begin{tabular}{lll}
\hline RESPONSE & NO. OF RESPONDENTS & PERCENTAGE \\
\hline Yes & 140 & $93.3 \%$ \\
No & 10 & $6.7 \%$ \\
Total & 150 & $100 \%$ \\
\hline
\end{tabular}

Source: yelwa, eta,al. 2015.

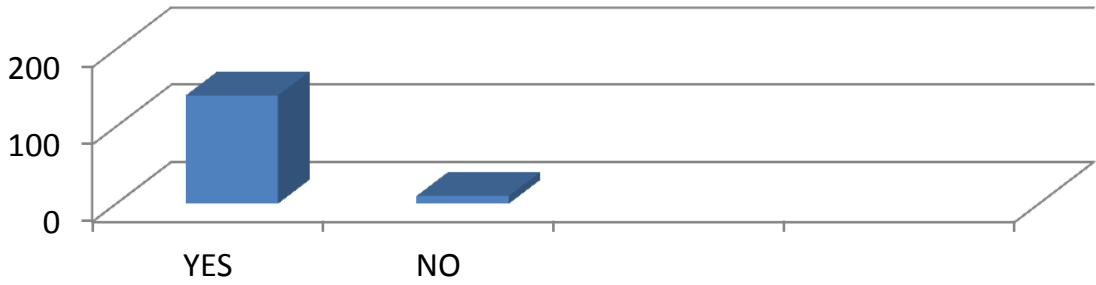

Figure. 4.6

Source: yelwa, eta,al. 2015.

Table: 4.6: Depicts tha 140 respondents representing $93.3 \%$ are of the opinion that IFS is capable of contributing to the development of SME's in North Central Nigeria while 10 respondents representing $6.7 \%$ are of the opinion that IFS is not capable of contributing to the development of SME's in North central Nigeria.

Table. 4.7 contributions IFS on employment generations

\begin{tabular}{lll}
\hline RESPONSE & NO. OF RESPONDENTS & PERCENTAGE \\
\hline Highly effective & 110 & $73.33 \%$ \\
Poorly effective & 40 & $26.67 \%$ \\
Total & 150 & $100 \%$ \\
\hline
\end{tabular}

Source: yelwa,eta,al. 2015.

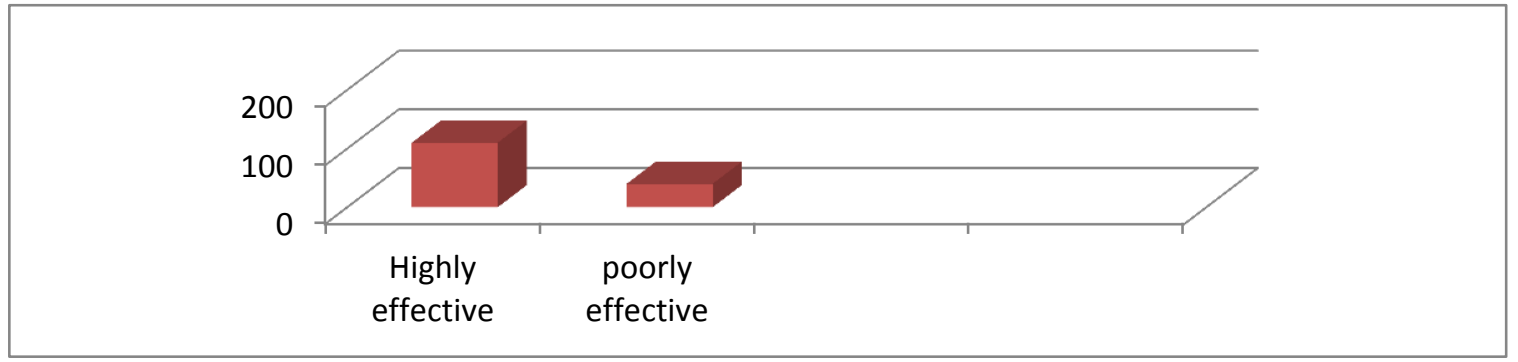

Figure. 4.7

Source: yelwa,eta,al. 2015.

Table $\mathrm{H}$ above shows that 110 respondents representing $73.33 \%$ are saying that IFS funding to employment generation is highly effective while 40 respondents representing $26.67 \%$ are of the opinion that IFS funding is poorly effective

\subsection{Presentation of Results From secondary data}

The multiple regressions is to be estimated, where the coefficients $\beta_{1}, \beta_{2}, \beta_{3}, \beta_{4}, \beta_{5}, \beta_{6}$ and $\beta_{7}$ to be estimated, are used to measure the contribution of independent variables to dependent variable.

The model is:

$$
\mathrm{L}=\beta_{0}+\beta_{1} \mathrm{EDU}+\beta_{2} \mathrm{LNR}+\beta_{3} \mathrm{REPL}+\beta_{4} \mathrm{GUAR}+\beta_{5} \mathrm{YAL}+\beta_{6} \mathrm{SMEDEV}+\beta_{7} \mathrm{EMPGEN}+\mu
$$


A simple linear Logit regression method of estimation was applied to our earlier outlined methods. The overall results are expressed as follows.

$=-2.945680+0.484543 E D U-0.501264 L N R-1.317809 R E P L-0.636474 G U A+4.49000 Y A L+0.870587 S M E D E V$
$+3.0088689 E M P G E N$
$Z=(-1.081706)(0.503867) \quad(-1.278817)$
$\begin{array}{ccc}(2.015625) & (14.77624) & (-0.832592)\end{array}$

McFadden $R^{2}=0.566939$

$S . E=0.288214$

\subsection{Interpretation of Results}

The logit regression result reveals that most of the variables have expected sign. However, the result shows that there is a positive but insignificant relationship between Education level of entrepreneur and growth in the north central Nigeria. This result concise with the outcome of Patrick et al., (2014) which says that educational level of an entrepreneur has a positive impact on economic growth in Nigeria. Furthermore, from Nguyen, (2003) empirical findings revealed that education is the most important factor affecting household credit facilities.

Bhat et al. (1999) also acknowledged that entrepreneur need formal education in order to comprehend complex information, keep business records, conduct cash flow analysis and make the right business decisions. He concluded that borrower with higher level of education may be considered for higher repayment rates. (Bhat and Tang, 2002).

Lending rate and repayment plan and revealed negative impact on growth; The inverse relationship that exists between these variables means that low value of them leads to increase in growth. This result also corresponds with the work of Mamudu, (2013), which identified an inverse relationship between lending rate and SMEs development in Ghana.

The result also shows that there is positive and significant relationship between Earning after loan (YAL), SMEs Development (SMEDEV), Employment generation and growth in North central Nigeria. This is in relation with Ahmed, (2008) that Informal Financial Sector plays a significant role on SMEs development, employment generation and income generation in Nigeria.

The McFadden R-squared value of 0.566939 implies that about 57 percent of the change in the dependent variable was explained by the explanatory variables of the model. It also shows that the model has a good fit.

Conclusively, the general findings of this study shows similarities with earlier studies but most important is that Informal Financial Sector (IFS) face unique problems among which are poverty-mentality, illiteracy, high inflation, low infrastructure and cultural loan-defaults; which affect their growth and profitability and hence, reduces their ability to contribute effectively to sustainable development.

\section{Conclusion and Recommendations}

The study examines the socio-economic impact of informal financial sector and inclusive growth in North Central Nigeria using Logit regression model for estimation. Based on the result, it is evidenced that there is positive and significance relationship between Earnings after loan, SMEs development, Employment generation and Informal Financial Sector in some selected North central states in Nigeria. We therefore reject all the null hypotheses that these independent variables [Earning after loan (YAL), SMEs development (SMEDEV) and Employment generation (EMPGEN)] has no significant relationship with informal Financial sector and therefore do not promote growth in North central Nigeria; while the alternative hypotheses be accepted because the result have proved that there are positive and significant relationship between the independent variables and the Informal Financial Sector and therefore promotes growth in the North central Nigeria.

However, the study recommends that education of the rural poor to embark on viable projects should be encouraged; infrastructural facilities should also be developed so as to reduce the overhead costs of the entrepreneurs which will also help to increase their revenue. The study also recommends favourable government policies so as to reduce loan defaults arising from unviable businesses while this will help to enhance more job creation.

\section{References}

Adamu, G. (2007), Role of Microfinance Institutions in Actualization of MDGs. Paper delivered at the induction ceremony of Institute of Chartered Economists of Nigeria (ICEN) in Port Harcourt. 
Adener S., \& Fitcbette, M. R. (1992). Partnership Financing of Microenterprises. International Journal of Social Economics, 24(12), 1470-1480.

Adeyemi, A. D. (2008). "The impact of Poverty on Economic Development", Journal of Finance, 12, 222-240

Ahmed A., (2008). "Impact of macro-economic factors on Total factor productivity in Sub-Saharan African countries"e. World Institute for Development Economics Research Paper, 39, 127-135

Ardener, B., \& Burman, J. (1995). The economics of microfinance (1st Edition) (Vol. First Edition): Massachuttes Institute of Technology.

Aryeetey, E., \& Udry, C. (1997). "The Characteristics of Informal Financial Markets in Sub-Saharan Africa”, Journal of African Economies, Supplement, 6(1), 161-203

Bauman, W. J., \& Hautman, S. (1988). "Entrepreneurship, Management, and the Structure of Payoffs", Cambridge, Massachusetts: MIT Press.

Berko, K. P. (2001). "Wealth Creation, Poverty Reduction and Social Justice - A World Council of Churches Perspectives", Paper on Conference on Religion and Globalization, Chiang Mau, Thailand, July - August.

Bhatt, N., \& Tang, S. (2002). "Determinants of Repayment in Micro Credit: Evidence from Programs in the United States", International Journal of Urban and Regional Research, 26(2) , 360-67.

Bhatt, N., Painter, G., \& Tang, S. (1999). "Can Microcredit Work in the United States"? Harvard Business Review: November/December 26-7.

CBN (2001). Annual Report and Statement of Account: Central Bank of Nigeria, Abuja.

CBN, (2000). Annual Report and Statement of Account: Central Bank of Nigeria, Abuja. Chukwu, D. A. (1990). Globalisation: Post Neo-dpendency and Poverty in Africa. Enugu: FourthDimension Publishing Co.

Dunn, A., \& Archucle, R. (2001) Financial System and Development; what role for formal and informal sector? Paris, OECD.

Essien, O. F. (2001). Financial Liberalization and Price Rigidity in Nigerian Banking system Managerial finance, 32(7).

Fazzari, S., Hubbard, R. G., \& Petersen, B. (1988). Financing constraints, corporate investment and Q. Brooking Papers on Economic Activity, 1, 41-195.

Hadji, A. (1999). Client Exist Surveys: A Tool for Understanding Client Drop-out. Journal of Microfinance, 2(1).

Hulme, D., \& Mosley, P. (1996). Finance Against Poverty. London: Routledge, 2.

Irobi, N. C. (2008). Microfinance and Poverty Alleviation: A case study of Obazu Progressive Women Association Mbieri, Imo State- Nigeria. Uppsala: Department of Economics

Johnson, S., McMillan, J., \& Woodruff, C. (2002). Property rights and finance. American Economic Review, 92(5), 1335-1357, http://dx.doi.org/10.1257/000282802762024539

Khandker, S. (2005). Micro-finance and Poverty: Evidence Using Panel Data from Bangladesh”. World Bank Economic Review.

Khandker, S., \& Khan, J. O. (1998). Fighting Poverty Microcredit. Dhaka, Bangladesh: University Press Limited

Kim, L., \& Nuggent, J. B. (1994); “The Republic of Korea's small and medium-sized Enterprises and their support systems", World Bank working paper No. 1404.

Mamudu, H. (2013). Great expectations: Microfinance and poverty reduction in Asia and Latin America.

McCulloch, C., \& Boulch, D. (2000). Theories of Entrepreneurship, Harvard University, U.S.A. http//:www.sdnetwork.kabissaoreneurshi2004.

Mckinnon, R. I. (1973). Money and Capital in Economic Development”. Washington D.C.; Institution.

Nguyen, H. (2003) Promise for the Poor: How Groups Build Microsavings; Kumarian Press, USA. Kimuyu, P. K. (1989)

Osuntogun, O. I., \& Adeyemo, P. O. (1981). Microcredit and microenterprise development: An analysis of some rural based enterprises in Nigeria. Nigeria Journal of Economics and Social Studies, 49(1), 95 - 113.

Otu MF et al (2003). Informal Credit Market and Monetary Management in Nigeria in Central Bank of Nigeria Research Department. Occas. Paper, 29.

Patrick, A. et al. (1996). "Microfinance, rural livelihoods, and women's Empowerment in Uganda" African Studies Centre Research Report 85 / 1996 
Shaw, E. S. (1973). "Financial Deepening in Economic Development” New York: Oxford University Press.

Toh, S., \& Urata, C. (1994). The Economics of Rotating Savings and Credit Associations; Evidence from the Jamaica partner: Journal of Development Economics, 60, 173-194.

World Bank (2000). Globalization, Growth and Poverty: Building an Inclusive world Economy.

World Bank (2007). Global Economic Monitoring Report 2007 World Bank (2008) World Development Indicators 2008 New York: Oxford University Press.

World Bank (2010). African Development Indicators 2005 New York: Oxford University Press.

World Bank Policy Research Report, New York: Oxford University Press

Wright, G. A. N. (2000). Microfinance Systems: Design Quality Financial Services for the Poor. Zeb Books Ltd, London \& New York, and The University Press Limited, Dhaka.

Yelwa, M. (2011). Informal financial sector and Financing of SMEs enterprises: Empirical evidence from Niger stateNigeria. PhD Thesis Deartment of Economics Usman Danfodiyo University, sokoto- Nigeria

Zaman, H. (2000). Assessing the Poverty and Vulnerability Impact of Microcredit in Bangladesh: A case study of BRAC. World Bank.

\section{Appendix: 1}

dependent Variable: L

Method: ML - Binary Logit (Quadratic hill climbing)

Date: 08/30/15 Time: 10:45

\begin{tabular}{cccrr}
\hline \hline Variable & Coefficient & Std. Error & z-Statistic & \multicolumn{1}{c}{ Prob. } \\
\hline \hline C & -2.945680 & 2.723180 & -1.081706 & 0.2794 \\
EDU & 0.484543 & 0.961649 & 0.503867 & 0.6144 \\
LNR & -0.501264 & 0.391975 & -1.278817 & 0.2010 \\
REPL & -1.317809 & 1.582779 & -0.832592 & 0.4051 \\
GUAR & -0.636474 & 1.594044 & -0.399283 & 0.6897 \\
YAL & $4.49 \mathrm{E}-06$ & $2.23 \mathrm{E}-06$ & 2.015625 & 0.0438 \\
SMEDEV & 0.870587 & 0.058918 & 14.77623 & 0.0000 \\
EMPGEN & 3.008689 & 0.860619 & 3.495959 & 0.0005 \\
\hline \hline McFadden R-squared & 0.566939 & Mean dependent var & 0.812081 \\
S.D. dependent var & 0.391965 & S.E. of regression & 0.288214 \\
Akaike info criterion & 0.657421 & Sum squared resid & 11.79559 \\
Schwarz criterion & 0.798546 & Log likelihood & -41.97786 \\
Hannan-Quinn criter. & 0.714758 & Deviance & 83.95571 \\
Restr. Deviance & 143.9912 & Restr. log likelihood & -71.99562 \\
LR statistic & 60.03552 & Avg. log likelihood & -0.281731 \\
Prob(LR statistic) & 0.000000 & & \\
\hline \hline Obs with Dep=0 & 28 & \multicolumn{2}{c}{ Total obs } & 149 \\
Obs with Dep=1 & 121 & & \\
\hline \hline
\end{tabular}

\section{$(\mathrm{cc}) \mathrm{BY}$}

This work is licensed under a Creative Commons Attribution 3.0 License. 